Tropical Journal of Pharmaceutical Research January 2020; 19 (1): 183-188

ISSN: $1596-5996$ (print); 1596-9827 (electronic)

(C) Pharmacotherapy Group, Faculty of Pharmacy, University of Benin, Benin City, 300001 Nigeria.

\title{
Comparison of efficacy and safety of teriparatide and hyaluronic acid - calcitonin combination treatments in Chinese osteoporotic patients with risk of bone fracture: A preliminary investigation
}

\author{
Changju Hou ${ }^{1}$, Jing $\mathrm{Li}^{2}$, Xuepeng Wang ${ }^{1}$, Liulong Zhu ${ }^{1}$, Maoqiang $\mathrm{Li}^{1 \text { * }}$ \\ ${ }_{1}^{1}$ Department of Orthopedic Surgery, Affiliated Hangzhou First People's Hospital, Zhejiang University School of Medicine, \\ ${ }^{2}$ Department of Radiology, Xiaoshan Traditional Chinese Medical Hospital of Hangzhou, Hangzhou, Zhejiang 310006, China \\ *For correspondence: Email: LaurelJocelyngPb@yahoo.com; Tel: +865715600 5600
}

\begin{abstract}
Purpose: To evaluate the efficacy and safety of teriparatide and hyaluronic-calcitonin combination treatment in Chinese osteoporotic patients with risk of bone fracture.

Methods: Osteoporotic patients aged 30 to 80 years, with at least one vertebral fracture and immediate risk of new vertebral fractures, were recruited from Hangzhou First People's Hospital. They were randomly assigned to two groups (50/group) treated with either teriparatide $(20 \mu \mathrm{g} /$ day) or hyaluronic acid + calcitonin (1:1 ratio, $200 \mathrm{IU}$ daily) for 12 months. The patients were followed up every 3 months. Bone mineral density (BMD) was evaluated using $x$-ray absorptiometry. The proportion of patients with new fractures was recorded. Changes in serum osteocalcin and serum bone alkaline phosphatase (BSAP) from baseline to endpoint were also measured.

Results: Treatment with teriparatide at a dose of $20 \mu \mathrm{g} /$ day resulted in a significant reduction in the proportion of patients with new fractures $(p<0.05)$, when compared to patients treated with a combination of hyaluronic acid + calcitonin (200 IU daily). Teriparatide treatment for 12 months resulted in significant increase in lumbar BMD. Significant increases in spine BMD were evident after 3 months of treatment. There were significantly greater increases in serum osteocalcin and BSAP levels in teriparatide-treated patients than in those given hyaluronic acid + calcitonin. The most common treatment adverse event reported by both sexes was dizziness.

Conclusion: These results demonstrate that teriparatide is efficacious and well tolerated in Chinese men and post-menopausal women with osteoporosis, when compared to the combination of hyaluronic acid and calcitonin. The efficacy of teriparatide is not associated with gender differences.
\end{abstract}

Keyword: Teriparatide, Calcitonin, Hyaluronic acid, Bone-specific alkaline phosphatase, Postmenopausal, Bone mineral density

This is an Open Access article that uses a fund-ing model which does not charge readers or their institutions for access and distributed under the terms of the Creative Commons Attribution License (http://creativecommons.org/licenses/by/4.0) and the Budapest Open Access Initiative (http://www.budapestopenaccessinitiative.org/read), which permit unrestricted use, distribution, and reproduction in any medium, provided the original work is properly credited.

Tropical Journal of Pharmaceutical Research is indexed by Science Citation Index (SciSearch), Scopus, International Pharmaceutical Abstract, Chemical Abstracts, Embase, Index Copernicus, EBSCO, African Index Medicus, JournalSeek, Journal Citation Reports/Science Edition, Directory of Open Access Journals (DOAJ), African Journal Online, Bioline International, Open-J-Gate and Pharmacy Abstracts

\section{INTRODUCTION}

Osteoporosis is one of the key causes of vertebral/non-vertebral fracture, especially in elderly people: every year, more than 1 million fractures in the Unites States are due to osteoporosis [1-3]. The disease is more common in women, especially postmenopausal women 
$[4,5]$. Therefore, several studies have focused mainly on women due to higher prevalence of bone fractures. However, osteoporosis-related mortality is higher in men than in women [6-8]. Thus, it is clinically important to identify safe and efficacious treatments for osteoporosis in the Asian population.

Teriparatide is an anti-resorptive agent usually applied in management of osteoporosis [9-11]. Several reports have shown that patients treated with teriparatide $(20 \mu \mathrm{g})$ had more than $60 \%$ reduction in the occurrence of bone fractures and reduction in the occurrence of non-traumatic fractures, relative to placebo-treated patients [1214]. Other studies reported that combination of teriparatide with hormone replacement therapy (HRT) significantly increased BMD in postmenopausal women, when compared to HRT [15-18]. Overall, teriparatide at the dose of $20 \mu \mathrm{g}$, is effective and well tolerated in the management of osteoporosis.

Calcitonin has been approved in China for the management of osteoporosis $[19,20]$. Several lines of clinical evidence have shown that calcitonin administration at a dose of $200 \mathrm{IU} /$ day significantly reduces vertebral fracture risk, and significantly increases lumbar spine BMD $[19,20]$. Moreover, the efficacy and safety of hyaluronic acid in management of osteoporosis are well established [21]. However, the efficacy and safety of teriparatide, relative to calcitoninhyaluronic acid combination in Chinese osteoporotic patients with risk of bone fractures, has not been investigated. Thus, the present study was designed to compare efficacy and safety of teriparatide and hyaluronic acidcalcitonin combination in Chinese osteoporosis patients with risk of bone fracture.

\section{METHODS}

\section{Patients and study design}

Osteoporosis patients aged 30 to 80 years, with at least one vertebral fracture, and high and immediate risk of new vertebral fractures, were recruited from Hangzhou First People's Hospital. They were randomly assigned to two groups treated with either teriparatide $(20 \mu \mathrm{g} /$ day $)$ or $1: 1$ mixture of hyaluronic acid + calcitonin at a dose of 200 IU daily, for 12 months. Calcium and vitamin D supplements were administered to all enrolled patients. Patients with a history of skeletal radiotherapy, suspected carcinoma or a history of carcinoma or any condition likely to affect the study-related outcome were excluded. Patients who had received treatments that are known to affect bone metabolism were excluded.
Moreover, patients with hypersensitivity to teriparatide or calcitonin, diluents or excipients of teriparatide or calcitonin were excluded. The study received approvals from ethics committee of the Institutional Review Board of Hangzhou First People's Hospital (vide EC approval no. IRB/2018-EC/HFPH-321), and the standard guidelines for animal care were followed [22].

\section{Efficacy and safety assessment}

The primary efficacy endpoint was to determine the proportion of patients with new vertebral fractures in both treatment groups. The secondary endpoint was to evaluate the effect of both treatments on BMD and biochemical markers of bone formation and resorption [serum osteocalcin and serum bone alkaline phosphatase (BSAP)]. Bone mineral density (BMD) was evaluated using $x$-ray absorptiometry. The proportion of patients with new fractures was recorded. In addition, changes in serum osteocalcin and BSAP from baseline to endpoint were measured. Safety was also evaluated.

\section{Statistical analysis}

Comparison of categorical/numerical variable data was done using appropriate statistical methods such as Chi-square/Fisher exact or unpaired $t$-test/Man Whitney. Numerical data with greater variation in response were analyzed using non-parametric test. All analyses were carried out using Statistical Package for the Social Sciences (SPSS) software. Percentage changes in lumbar spine BMD and biomarkers from baseline were analyzed using $t$-test or Wilcoxon signed rank test. Comparison of numerical data with confounding variables was done using analysis of covariance. Statistical significance of difference was assumed at $p>$ 0.05 .

\section{RESULTS}

\section{Patients profile and demography}

A total of 100 patients with osteoporosis were recruited (50 per group), and data were included in statistical analysis. Demography and baseline characteristic were similar in both treatment groups (Table 1).

\section{Incidence of fracture}

Treatment with teriparatide at a dose of 20 $\mu \mathrm{g} /$ day resulted in statistically significant reduction in the proportion of patients with new fractures, when compared to patients treated 
with combination of hyaluronic acid + calcitonin at a dose of $200 \mathrm{IU}$ daily (Table 2). The patients treated with teriparatide had lower risk of vertebral fractures and non- vertebral fractures, when compared to those treated with $C A L+H A$.

\section{Bone mineral density}

In women, treatment with teriparatide at a dose of $20 \mu \mathrm{g} /$ day (LS mean: 8.2) for 12 months resulted in statistically significant increases in lumbar BMD, when compared with patients treated with $\mathrm{CA}+\mathrm{HA}$ (LS mean: 1.2), with LSM diff. ( $\mathrm{f} 95 \% \mathrm{Cl}$ ) of $7.1(6.2,7.7 ; p<0.01)$. In men, treatment with teriparatide at a dose of $20 \mu \mathrm{g} / \mathrm{day}$ (LS mean: 6.3) for 12 months resulted in statistically significant increases in lumbar BMD, when compared with those treated with $\mathrm{CA}+\mathrm{HA}$ (LS mean: 0.57$)$, with LSM diff. $(95 \% \mathrm{Cl})$ of 5.7 $(4.7,6.6 ; p<0.01)$. Statistically significant increases in spine BMD were evident after 3 months of treatment.

\section{Effect of treatments on biochemical markers}

In men and women, significantly greater increase in level of serum osteocalcin was observed after treatment with teriparatide for 12 months, when compared with treatment with hyaluronic acid + calcitonin. Favorable improvement in serum osteocalcin from baseline was observed in teriparatide-treated patients even after 1 month of treatment (Table 3).

After 12 months of treatment, the percentage change in bone-specific alkaline phosphatase from baseline to endpoint (12 months) in Chinese patients (men and women) with osteoporosis was significantly greater in patients treated with teriparatide than in those who received hyaluronic acid + calcitonin. Favorable improvement in BSAP from baseline was observed in teriparatide-treated patients as early as 1 month of treatment (Table 4).

Table 1: Demography and baseline clinical characteristics of the patients

\begin{tabular}{|c|c|c|c|}
\hline Variable & $\begin{array}{l}\text { Teriparatide } \\
(n=50)\end{array}$ & $\begin{array}{c}\text { CAL+ HA } \\
(n=50)\end{array}$ & $P$-value \\
\hline Age (years) & $69(7.5)$ & $68(7.2)$ & $>0.05^{\star}$ \\
\hline $\begin{array}{l}\text { Sex } \\
\text { Female/male (\%) }\end{array}$ & $60 / 40$ & $65 / 35$ & $>0.05^{\star \star}$ \\
\hline $\begin{array}{l}\text { Weight }(\mathrm{kg}) \\
\text { BMI }\left(\mathrm{kg} / \mathrm{m}^{2}\right)\end{array}$ & $\begin{array}{l}69.4 \pm 6.4 \\
25.2(3.4)\end{array}$ & $\begin{array}{l}71.8 \pm 5.6 \\
24.9(3.5)\end{array}$ & $\begin{array}{l}>0.05^{*} \\
>0.05^{\star}\end{array}$ \\
\hline $\begin{array}{l}\text { Treatment duration } \\
\text { (months) }\end{array}$ & $5.2(1.4)$ & $5.3(1.2)$ & $>0.05^{\star}$ \\
\hline Vertebral BMD (\%) & 0.7 & 0.8 & $>0.05^{\star \star}$ \\
\hline $\begin{array}{l}\text { Non-vertebral BMD (\%) } \\
\text { Percentage of patients }\end{array}$ & 0.8 & 0.8 & $>0.05^{\star *}$ \\
\hline $\begin{array}{l}\text { taking osteoporosis } \\
\text { medication (\%) }\end{array}$ & 15.0 & 14.3 & $>0.05^{\star *}$ \\
\hline
\end{tabular}

Data for age, weight, BMI, and treatment duration are presented as mean \pm SD; CLA + HA= calcitonin + hyaluronic acid

Table 2: Summary of new fracture incidence between the two treatment groups

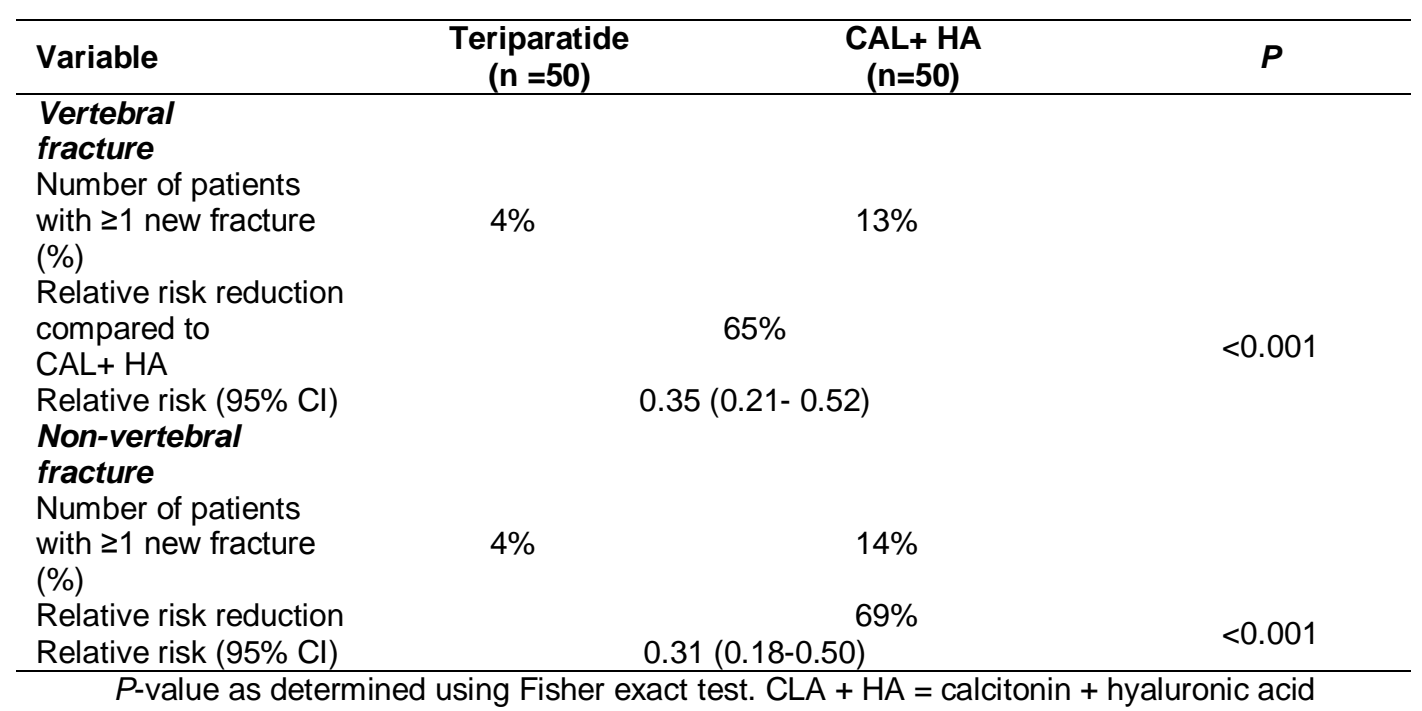


Table 3: Changes in serum osteocalcin in Chinese patients with osteoporosis

\begin{tabular}{|c|c|c|c|c|c|c|}
\hline \multirow[b]{3}{*}{$\begin{array}{l}\text { Time } \\
\text { point }\end{array}$} & \multicolumn{6}{|c|}{ Patients } \\
\hline & \multicolumn{3}{|c|}{ Women } & \multicolumn{3}{|c|}{ Men } \\
\hline & $\begin{array}{l}T P T \\
(n=50)\end{array}$ & $\begin{array}{l}C A L+H A \\
(n=50)\end{array}$ & $\begin{array}{l}\text { Difference } \\
\text { (TPT } \\
\text { VS } \\
C A L+H A)\end{array}$ & $\begin{array}{l}T P T \\
(n=50)\end{array}$ & $\begin{array}{l}C A L+H A \\
(n=50)\end{array}$ & $\begin{array}{l}\text { Difference } \\
\text { (TPT } \\
\text { VS } \\
C A L+H A)\end{array}$ \\
\hline $\begin{array}{l}\text { Baseline } \\
\text { (Median) }\end{array}$ & 20 & 20 & - & 18.0 & 17 & - \\
\hline $\begin{array}{l}12 \text { months } \\
\text { (Median) }\end{array}$ & 52 & 18 & - & 28.0 & 12.0 & - \\
\hline$P$-value & 0.001 & & 0.001 & 0.001 & & 0.001 \\
\hline
\end{tabular}

Note: CLA + HA = calcitonin + hyaluronic acid; TPT = teriparatide

Table 4: Change in bone-specific alkaline phosphatase from baseline to endpoint (12 months) in Chinese patients with osteoporosis

\begin{tabular}{|c|c|c|c|c|c|c|}
\hline \multirow[b]{2}{*}{$\begin{array}{l}\text { Time } \\
\text { point }\end{array}$} & \multicolumn{3}{|c|}{ Women } & \multicolumn{3}{|c|}{ Men } \\
\hline & $\begin{array}{c}T P T \\
(n=50)\end{array}$ & $\begin{array}{c}C A L+H A \\
(n=50)\end{array}$ & $\begin{array}{c}\text { Difference } \\
\text { (TPT } \\
\text { vs } \\
C A L+H A)\end{array}$ & $\begin{array}{c}T P T \\
(n=50)\end{array}$ & $\begin{array}{c}C A L+H A \\
(n=50)\end{array}$ & $\begin{array}{c}\text { Difference } \\
\text { (TPT } \\
\text { vs } \\
\text { CAL+HA) }\end{array}$ \\
\hline $\begin{array}{l}\text { Baseline } \\
\text { (median) }\end{array}$ & 11 & 12 & - & 10 & 12 & - \\
\hline $\begin{array}{l}12 \text { months } \\
\text { (median) }\end{array}$ & 18 & 10 & - & 14 & 10.4 & - \\
\hline $\begin{array}{l}\% \text { change } \\
\text { (median) } \\
P \text {-value }\end{array}$ & $\begin{array}{c}52 \\
0.001\end{array}$ & $\begin{array}{c}-9 \\
0.01\end{array}$ & 0.001 & $\begin{array}{c}29 \\
0.001\end{array}$ & $\begin{array}{c}-16 \\
0.001\end{array}$ & 0.001 \\
\hline
\end{tabular}

Note: CLA + HA = calcitonin + hyaluronic acid; TPT: teriparatide

\section{Safety profile}

More than $30 \%$ of patients (33\%) experienced at least 1 TEAE in both treatment groups (Table 5). However, only 3 patients experienced TEAEs possibly related to teriparatide. There were no mortalities in any of the groups.

Table 5: Summary of adverse events in Chinese patients treated with teriparatide

\begin{tabular}{lcc}
\hline & \multicolumn{2}{c}{ Patients } \\
\cline { 2 - 3 } Variable & Women & Men \\
& TPT $(\boldsymbol{n}=50)$ & TPT $(\boldsymbol{n}=50)$ \\
& $\boldsymbol{n}(\%)$ & $\boldsymbol{n}(\%)$ \\
\hline SAEs $(\%)$ & 4 & 4 \\
TEAEs $(\%)$ & 33 & 33 \\
\hline
\end{tabular}

The most common TEAE reported in both sexes was dizziness (Table 6).

\section{DISCUSSION}

This is the first investigation to evaluate the efficacy and safety profile of teriparatide in the treatment of osteoporosis in China. Treatment with teriparatide at a dose of $20 \mu \mathrm{g} /$ day for 12 months resulted in statistically significant increases in lumbar BMD, and statistically significant reduction in the proportion of patients with new fractures, when compared to the patients treated with combination of hyaluronic acid + calcitonin at a dose of 200 IU/day. A significant increase in BMD was observed after teriparatide treatment, when compared to the patients treated with combination of hyaluronic acid + calcitonin. Similar results have been reported in other studies: a subset of patients examined in a study in which postmenopausal women were treated with placebo or teriparatide in a dose range of 20-40 ug/day showed significant changes in BMD from baseline [1219].

Furthermore, teriparatide was found to have superior efficacy profile over calcitonin in terms of enhancement of LS BMD [7]. In this study, teriparatide treatment improved median serum levels of bone biomarkers, while calcitonin decreased median serum osteocalcin levels. Regardless of sex, teriparatide treatment reduced the risk of new vertebral fracture, significantly increased BMD, and also improved 
serum levels of the bone biomarker osteocalcin, while calcitonin decreased median serum osteocalcin levels. The efficacies of teriparatide and calcitonin treatments on serum levels of osteocalcin are consistent with their mechanisms of action.

Table 6: Summary of Adverse Events in Chinese patients with osteoporosis

\begin{tabular}{|c|c|c|}
\hline $\begin{array}{l}\text { Preferred } \\
\text { term }\end{array}$ & & $\begin{array}{c}\text { AE possibly } \\
\text { related to TPT } \\
\text { (\% of patients) }\end{array}$ \\
\hline $\begin{array}{l}\text { Patients with } \geq 1 \\
\text { TEAEs/SAEs }\end{array}$ & 33 & 13 \\
\hline Dizziness & 8 & 4 \\
\hline $\begin{array}{l}\text { Alanine } \\
\text { aminotransferase } \\
\text { increased }\end{array}$ & 4 & 4 \\
\hline $\begin{array}{l}\text { Aspartate } \\
\text { aminotransferase } \\
\text { increased }\end{array}$ & 4 & 4 \\
\hline Asthenia & 4 & 4 \\
\hline $\begin{array}{l}\text { Blood alkaline } \\
\text { phosphatase } \\
\text { increased }\end{array}$ & 4 & 4 \\
\hline $\begin{array}{l}\text { Blood creatine } \\
\text { phosphokinase } \\
\text { increased }\end{array}$ & 4 & 4 \\
\hline $\begin{array}{l}\text { Blood uric acid } \\
\text { increased }\end{array}$ & 4 & 4 \\
\hline Cerebral infarction & 4 & 0 \\
\hline Clavicle fracture & 4 & 0 \\
\hline Diarrhea & 4 & 0 \\
\hline $\begin{array}{l}\text { Gamma glutamyl } \\
\text { transferase } \\
\text { increased }\end{array}$ & 4 & 4 \\
\hline Multi-organ failure & 4 & 0 \\
\hline Nasopharyngitis & 4 & 0 \\
\hline Pain in extremity & 4 & 0 \\
\hline $\begin{array}{l}\text { Plasma cell } \\
\text { myeloma }\end{array}$ & 4 & 0 \\
\hline $\begin{array}{l}\text { Pulmonary } \\
\text { infarction }\end{array}$ & 4 & 0 \\
\hline Thirst & 4 & 4 \\
\hline
\end{tabular}

Teriparatide preferentially stimulates osteoblasts while calcitonin acts as an anti-osteoclastic agent. The effect of teriparatide on osteocalcin is consistent with previous findings [19]. In the present study, gradual increases in serum bonespecific alkaline phosphatase were also observed after treatment with teriparatide. This was possibly due to the effect of teriparatide on osteoblast activity and its active involvement in bone formation. Overall, the effect of teriparatide on bone biomarkers (osteocalcin and alkaline phosphatase) was similar in both sub-groups (men and women). This suggests that there are no gender differences in efficacy of teriparatide with respect to its effect on osteocalcin or bonespecific alkaline phosphatase.

The most common adverse event seen was dizziness. Teriparatide was safe and well tolerated among Chinese patients with osteoporosis, and the incidence of TEAEs was similar among Chinese men and women. The results of the present study showed that there were no gender differences in efficacy and safety of teriparatide among patients with osteoporosis.

Since the present trial was conducted at a single hospital in China, the findings cannot to be generalized to the Chinese population. Moreover, the sample size used was small. Thus, a large clinical trial with appropriate sample size is needed to confirm the present findings.

\section{CONCLUSION}

The present study has demonstrated that teriparatide (at a dose of $20 \mu \mathrm{g} /$ day) is efficacious and well tolerated in Chinese men and postmenopausal women with osteoporosis, when compared to combination of hyaluronic acid and calcitonin. Moreover, the results suggest that there are no gender differences in efficacy of teriparatide.

\section{DECLARATIONS}

\section{Conflict of interest}

No conflict of interest is associated with this work.

\section{Contribution of authors}

We declare that this work was done by the authors named in this article and all liabilities pertaining to claims relating to the content of this article will be borne by the authors. This manuscript was drafted by Changju Hou. Changju Hou and Jing Li, Xuepeng Wang, Liulong Zhu performed experiments under supervision of Maoqiang Li. Jing Li, Xuepeng Wang performed the statistical analysis for this study.

\section{Open Access}

This is an Open Access article that uses a funding model which does not charge readers or their institutions for access and distributed under the terms of the Creative Commons Attribution License (http://creativecommons.org/licenses/by/ 4.0) and the Budapest Open Access Initiative (http://www.budapestopenaccessinitiative.org/rea 
d), which permit unrestricted use, distribution, and reproduction in any medium, provided the original work is properly credited.

\section{REFERENCES}

1. Siddiqui NA, Shetty KR, Duthie EH Jr. Osteoporosis in older men: discovering when and how to treat it. Geriatrics 1999; 54(9): 20-2, 27-8, 30 passim.

2. Watts NB, Adler RA, Bilezikian JP, Drake MT, Eastell R, Orwoll ES, Finkelstein JS, Endocrine Society. Osteoporosis in men: an Endocrine Society clinical practice guideline. J Clin Endocrinol Metab 2012; 97: 1802-1822.

3. Forsén L, Sogaard AJ, Meyer HE, Edna T, Kopjar B. Survival after hip fracture: short- and long-term excess mortality according to age and gender. Osteoporos Int 1999; 10: 73-78.

4. Haentjens $P$, Magaziner J, Colón-Emeric CS, Vanderschueren $D$, Milisen $K$, Velkeniers $B$, Boonen $S$. Meta-analysis: excess mortality after hip fracture among older women and men. Ann Intern Med 2010; 152: 380 390.

5. Holt G, Smith R, Duncan K, Hutchison JD, Gregori A. Gender differences in epidemiology and outcome after hip fracture: evidence from the Scottish Hip Fracture Audit. J Bone Joint Surg 2008; 90B: 480-483.

6. Zhang $Z Q$, Ho SC, Chen ZQ, Zhang $C X$, Chen $Y M$. Reference values of bone mineral density and prevalence of osteoporosis in Chinese adults. Osteoporos Int, 2014; 25: 497-507.

7. Tsai K, Twu S, Chieng P, Yang R, Lee T. Prevalence of vertebral fractures in Chinese men and women in urban Taiwanese communities. Calcif Tissue Int 1996; 59: 249-253.

8. Orwoll ES, Scheele WH, Paul S, Adami S, Syversen U, Diez-Perez A, Kaufman JM, Clancy AD, Gaich GA. The effect of teriparatide [human parathyroid hormone (134)] therapy on bone density in men with osteoporosis. $J$ Bone Miner Res 2003; 18: 9-17.

9. Sethi BK, Chadha M, Modi KD, Kumar KM, Mehrotra R, Sriram U. Efficacy of teriparatide in increasing bone mineral density in postmenopausal women with osteoporosis-an Indian experience. J Assoc Physicians India 2008; 56: 418-424.

10. Cusano NE, Costa AG, Silva BC, Bilezikian JP. Therapy of osteoporosis in men with teriparatide. $J$ Osteoporos 2011: 463675, doi: 10.4061/2011/463675.

11. Hodsman AB, Bauer DC, Dempster DW, Dian L, Hanley $D A$, Harris ST, Kendler DL, McClung MR, Miller PD, Olszynski WP, et al. Parathyroid hormone and teriparatide for the treatment of osteoporosis: a review of the evidence and suggested guidelines for its use. Endocr Rev 2005; 26: 688-703.

12. Neer RM, Arnaud $C D$, Zanchetta JR, Prince R, Gaich $G A$, Reginster JY, Hodsman $A B$, Eriksen EF, IshShalom S, Genant HK, et al. Effect of parathyroid hormone (1-34) on fractures and bone mineral density in postmenopausal women with osteoporosis. $N$ Engl $J$ Med 2001; 344: 1434-1441.

13. Kurland ES, Cosman F, McMahon DJ, Rosen CJ, Lindsay R, Bilezikian JP. Parathyroid hormone as a therapy for idiopathic osteoporosis in men: effects on bone mineral density and bone markers. J Clin Endocrinol Metab 2000; 85: 3069-3076.

14. Kaufman JM, Orwoll E, Goemaere S, San Martin J, Hossain A, Dalsky GP, Lindsay $R$, Mitlak BH. Teriparatide effects on vertebral fractures and bone mineral density in men with osteoporosis: treatment and discontinuation of therapy. Osteoporos Int 2005; 16: 510-516.

15. Finkelstein JS, Hayes A, Hunzelman JL, Wyland JJ, Lee $H$, Neer RM. The effects of parathyroid hormone, alendronate, or both in men with osteoporosis. N Engl J Med 2003; 349: 1216-1226.

16. Bhudhikanok GS, Wang MC, Eckert K, Matkin C, Marcus $R$, Bachrach LK. Differences in bone mineral in young Asian and Caucasian Americans may reflect differences in bone size. J Bone Miner Res 1996; 11: 1545-1556.

17. Langdahl BL, Marin F, Shane E, Dobnig H, Zanchetta JR, Maricic M, Krohn K, See K, Warner MR. Teriparatide versus alendronate for treating glucocorticoid-induced osteoporosis: an analysis by gender and menopausal status. Osteoporos Int 2009; 20(12): 2095-2104.

18. Rosen CJ, Bilezikian JP. Clinical review 123: Anabolic therapy for osteoporosis. J Clin Endocrinol Metab 2001; 86: 957-964.

19. Muñoz-Torres M, Alonso G, Raya MP. Calcitonin therapy in osteoporosis. Treat Endocrinol 2004; 3(2): 117-132.

20. Mehta NM, Malootian A, Gilligan JP. Calcitonin for osteoporosis and bone pain. Curr Pharm Des 2003; 9(32): 2659-2676.

21. Kootala S, Ossipov D, van den Beucken JJ, Leeuwenburgh S, Hilborn J. Bisphosphonatefunctionalized hyaluronic acid showing selective affinity for osteoclasts as a potential treatment for osteoporosis. Biomater Sci 2015; 3(8): 1197-1207.

22. Bryan EO, Wanyong $P$, Takashi A, Byeong $H L$. Laboratory Animal Laws, Regulations, Guidelines and Standards in China Mainland, Japan, and Korea. ILAR Journal 2016; 57 (3): 301-311. 